\title{
FUZZY INFERENCE SYSTEM DALAM MENENTUKAN STATUS MALNUTRITION PADA BALITA DI KOTA BATAM
}

\author{
Pastima Simanjuntak, Cosmas Eko Suharyanto \\ DosenTeknik Informatika Universitas Putera Batam \\ Jl. R SoepraptoMuka Kuning Batam \\ p.lastria@gmail.com,costmust@gmail.com
}

\begin{abstract}
ABSTRAK
Batam merupakan salah satu kota dengan perindustrian termaju dibagian barat Indonesia. Industri di Kota Batam dibagi menjadi industri berat dan industri ringan. Industri berat didominasi oleh industri galangan kapal, industri logam dan industri baja. Sedangkan industri ringan meliputi, industri elektronika, industri garmen andindustri plastic. Salah satu faktor kesehatan yang terjadi di Kota Batam, yakni masih banyaknya anak-anak yang mengalami kekurangan gizi. Gizi buruk adalah badan atau tubuh yang mengalami kekurangan gizi dalam waktu yang cukup lama dan umumnya terjadi pada anak-anak, gizi buruk pada anak disebabkan oleh kurangnya asupan makanan bergizi seimbang, di samping itu bisa juga disebabkan oleh penyakit-penyakit tertentu yang menyebabkan terganggunya proses pencernaan makanan ataupun terganggunya penyerapan zat gizi penting yang diperlukan oleh tubuh. Dalam dunia kesehatan Gizi Buruk disebut sebagai Malnutrisi Energi Protein (MEP) Berat, Penyelesaian masalah ini menggunakan fuzzy logic dengan metode Sugeno. Metode ini menggunakan konstanta atau fungsi matematika dari variabel input, dan pada proses defuzzifikasinya mengunakan metode rata-rata terpusat. Hasil nilai outputstatus malnutrition 83.85 yang berarti tidak termasuk dalam status malnutrition.
\end{abstract}

Kata kunci: Fuzzy Logic, Malnutrition, Metode Sugeno

\begin{abstract}
Batam is one of the most advanced industrial cities in the western part of Indonesia. The industry in Batam City is divided into heavy industry and light industry. Heavy industry is dominated by shipyard industry, metal industry, and steel industry. While the light industry includes the electronics industry, garment industry and plastic industry. One of the health factors that occurred in the city of Batam, namely there are still many children who experience malnutrition. Malnutrition is a body or body that experiences malnutrition for a long time and generally occurs in children, malnutrition in children is caused by a lack of balanced nutritious food intake, besides that it can also be caused by certain diseases that cause disruption of the process digestion of food or disruption of absorption of important nutrients needed by the body. In the world of Bad Nutrition health is called Heavy Protein Energy Malnutrition (MEP), the solution to this problem is using fuzzy logic with the Sugeno method. This method uses constants or mathematical functions from input variables, and in the defuzzification process uses a centralized average method.The output value of malnutrition status is 83.85 which means it is not included in malnutrition status.
\end{abstract}

Keywords : Fuzzy Logic, Malnutrition, Sugeno Method 


\section{PENDAHULUAN}

Kota Batam merupakan salah satu kota dengan perindustrian termaju dibagian barat Indonesia. Industri di Kota Batam dibagi menjadi industri berat dan industri ringan. Industri berat didominasi oleh industri galangan kapal, industri logam, industri baja dan lain sebagainya. Sedangkan industri ringan meliputi, industri elektronika, industri garmen, industri plastik dan lain sebagainya. Lokasi perindustrian di Kota Batam tersebar dibeberapa tempat yang disesuaikan dengan jenis dan hasil produksi dari perusahaan tersebut. Di lihat dari letak geografisnya, Kota Batam berada pada jalur yang sangat strategis, yaitu berada pada jalur pelayaran dunia internasional dengan lokasi yang berdekatan dengan Malaysia dan Singapura, dan boleh dikatakan dua negara tersebut merupakan negara dengan tingkat perekonomian, perindustrian dan teknologi terbaik di kawasan Asia Tenggara, sehingga tidak salah kalau pemerintah Kota Batam selalu menyuarakan Kota Batam harus menjadi kota dengan masyarakat yang madani, di mana masyarakatnya ikut berperan serta dalam pembangunan kota, selain itu Kota Batam memiliki fungsi istimewa yaitu sebagai bandar pelayaran dunia internasional, sehingga penggunaan sistem teknologi informasi merupakan suatu keharusan yang wajib diterapkan pelaku industri di Kota Batam.
Salah satu faktor kesehatan yang terjadi di Kota Batam, yakni masih banyaknya anakanak yang mengalami kekurangan gizi. Gizi buruk adalah kondisi tubuh terparah yang mengalami kekurangan gizi dalam kurun waktu yang lama. Hal ini umumnya terjadi pada anak-anak, gizi buruk pada anak disebabkan oleh kurangnya asupan makanan bergizi seimbang, di samping itu bisa juga disebabkan oleh penyakit-penyakit tertentu yang menyebabkan terganggunya proses pencernaan makanan ataupun terganggunya penyerapan zat gizi penting yang diperlukan oleh tubuh.

Dalam istilah medis Gizi Buruk disebut sebagai Malnutrisi Energi Protein (MEP) Berat, MEP itu sendiri ada dua macam yaitu MEP ringan dan berat. Pada MEP ringan disebut juga sebagai gizi kurang, belum menunjukkan gejala klinis yang khas, anak yang mengalami gizi kurang hanya terlihat kurus dan gangguan pertumbuhan. Sedangkan MEP berat atau gizi buruk, anak sudah memiliki gejala-gejala klinis yang khas beserta gangguan biokimiawi dalam tubuh. Gizi buruk dikenal juga dengan sebutan Busung Lapar yang memiliki tiga bentuk klinis, yaitu Marasmus, Kwashiorkor, dan Marasmus-Kwashiorkor.

Konsep fuzzy logic diperkenalkan oleh Prof. Lotfi Zadeh dari Universitas California di Berkeley pada 1965. Secara umum, fuzzy logic adalah sebuah metodologi "berhitung" dengan variabel kata-kata (linguistic 
variable), sebagai pengganti berhitung dengan bilangan (N. Agus, 2009). Katakata yang digunakan dalam fuzzylogic memang tidak seperti bilangan, namun kata-kata jauh lebih dekat dengan intuisi manusia. Manusia bisa langsung "merasakan" nilai dari variabel kata-kata yang sudah dipakainya sehari-hari.

\section{METODE PENELITIAN}

Desain penelitian merupakan tahapantahapan dalam menyusun suatu karya ilmiah untuk memperoleh bukti-bukti yang empiris dalam menjawab pertanyaan terhadap penelitian tersebut. Adapun tahapan-tahapan dalam desain penelitian ini adalah sebagai berikut:

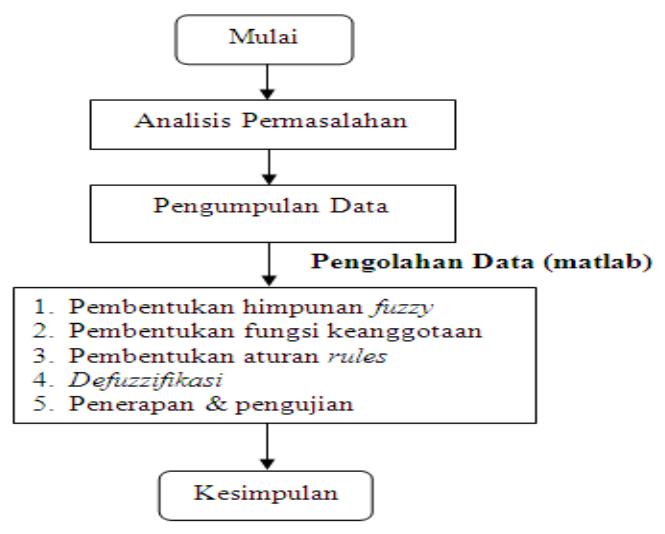

Gambar 1. Desain Penelitian

Sistem inferensi fuzzy menggunakan metode Sugeno, memiliki karakteristik yaitu konsekuen tidak merupakan himpunan fuzzy, namun merupakan suatu persamaan linier dengan variabelvariabel sesuai dengan variabel-variabel inputnya. Metode ini diperkenalkan oleh Takagi-Sugeno Kang pada tahun 1985. Ada 2 model untuk sistem inferensi fuzzy dengan menggunakan metode TSK, yaitu model TSK orde-0 dan model TSK orde- 1 . Dalam banyak hal, metode Sugeno mirip dengan metode Mamdani. Perbedaan terletak pada jenis fungsi keanggotaan yang dipakai dalam bagian consequent. Tahapan dari proses ini adalah: 1)Menentukan variabel masukan. 2)Proses fuzzifikasi.3) operasi logika fuzzy dimana perlu dilakukan jika bagian antecedent lebih dari satu pernyataan melakukan operasi-operasi logika fuzzy. Hasil dari tahap proses ini adalah derajat kebenaran antecedent yang berupa bilangan tunggal. Operator fuzzy untuk melakukan operasi AND dan OR bisa dibuat sendiri. 4) Proses implikasi: menerapkan metode implikasi untuk menentukan bentuk akhir fuzzyset keluaran. Consequent atau keluaran dari aturan fuzzy ditentukan dengan mengisikan keanggotaan keluaran yang bersifat linier atau konstan. 5) Agregasi yaitu proses mengkombinasikan keluaran dimana keluaran bukan dalam bentuk fungsi keanggotaan, tetapi sebuah bilangan yang mana berubah secara linier.

Adapun variabel yang peneliti gunakan adalah sebagai berikut:

a. Variabel Input 


\section{Jurnal EdikInformatika E-ISSN : 2541-3716}

Penelitian Bidang Komputer Sains dan Pendidikan Informatika

1) Usia Balita

2) Tinggi Badan Balita

3) Berat Badan Balita

b. Variabel Output

\section{1) Status Malnutrition}

Dalam melalukan penelitian ini metode yang dikumpulkan dalam pengambilan data adalah:

\section{A. Penetitian Lapangan (Field Research)}

Meneliti dalam melalukan pengamatan pada Kota Batam Kepri Indonesia, yang menjadi objek penelitian dengan teknikteknik seperti observasi dan wawancara.

\section{B.Penelitian Perpustakaan (Library} Research) Penelitian yang dilakukan melalui literatur-literatur yang berhubungan dengan tema penelitian, untuk mencari informasi menyusun teoriteori yang berhubungan dengan pembahasan sehingga terjadi perpanduan (interaksi) yang kompleks antara yang satu dengan yang lainnya.

C. Penelitian Laboraturium (Laboratory Research).

Penelitian yang dilakukan dilaboratirium komputer yang di gunakan untuk menggadakan praktek langsung dengan komputer untuk menggunakan aplikasi matlab yang akan menunjang atau mengetahui kepuasan masyarakat sehingga menghasilkan informasi yang layak.

\section{HASIL PENELITIAN}

Dalam menentukan perancangan sistem, terdapat 3 variabel input dan 1 variabel output. Yang mana variabel input terdiri atas Usia Balita, Tinggi Badan Balita dan Berat Badan Balita. Variabel output keputusan atau decision adalah status malnutrition.

Tabel 1.Himpunan Kabur

\begin{tabular}{|c|c|c|}
\hline Variabel & Nama Himpunan Fuzzy & Domain \\
\hline \multirow[t]{4}{*}{ Usia Balita } & Usia Sangat Tinggi & [25 60] \\
\hline & Usia Tinggi & {$\left[\begin{array}{ll}13 & 36\end{array}\right]$} \\
\hline & Usia Cukup & [724] \\
\hline & Usia Rendah & {$\left[\begin{array}{ll}0 & 12\end{array}\right]$} \\
\hline \multirow[t]{4}{*}{ Tinggi Badan } & Sangat Tinggi & [110130] \\
\hline & Tinggi & [91120] \\
\hline & Kurang Tinggi & [71100] \\
\hline & Tidak Tinggi & [6180] \\
\hline Berat Badan & Sangat Berat & {$\left[\begin{array}{ll}18 & 26\end{array}\right]$} \\
\hline
\end{tabular}




\begin{tabular}{|l|l|l|}
\hline \multirow{2}{*}{ Keputusan } & Berat & {$\left[\begin{array}{ll}12 & 19\end{array}\right]$} \\
\cline { 2 - 3 } & Kurang Berat & {$[813]$} \\
\cline { 2 - 3 } & Tidak Berat & {$[69]$} \\
\hline & Ya & {$\left[\begin{array}{ll}0 & 0.4\end{array}\right]$} \\
\cline { 2 - 3 } & Tidak & {$\left[\begin{array}{ll}0.5 & 1\end{array}\right]$} \\
\hline
\end{tabular}

Tabel 2.Himpunan Fuzzy Variabel Usia Balita

\begin{tabular}{|l|l|l|l|l|}
\hline $\begin{array}{l}\text { Semesta } \\
\text { pembicaraan }\end{array}$ & $\begin{array}{l}\text { Nama Himpunan } \\
\text { fuzzy }\end{array}$ & Model MF & Parameter & Domain \\
\hline $0-60$ & Usia Sangat Tinggi & Trimf & {$[2540$ 60] } & {$[25-60]$} \\
\hline $0-60$ & Usia Tinggi & Trimf & {$\left[\begin{array}{lll}1330 & 36\end{array}\right]$} & {$[13-36]$} \\
\hline $0-60$ & Usia Kurang Tinggi & Trimf & {$[72024]$} & {$[7-24]$} \\
\hline $0-60$ & Usia Rendah & Trimf & {$\left[\begin{array}{lll}0 & 10 & 12\end{array}\right]$} & {$[0-12]$} \\
\hline
\end{tabular}

Tabel 3.Himpunan Fuzzy variabel Tinggi Badan Balita

\begin{tabular}{|l|l|l|l|l|}
\hline $\begin{array}{l}\text { Semesta } \\
\text { pembicaraan }\end{array}$ & $\begin{array}{l}\text { Nama himpunan } \\
\text { fuzzy }\end{array}$ & Model MF & Parameter & Domain \\
\hline $0-130$ & Sangat tinggi & Trimf & {$\left[\begin{array}{lll}110120 & 130\end{array}\right]$} & {$\left[\begin{array}{ll}110130\end{array}\right]$} \\
\hline $0-130$ & Tinggi & Trimf & {$\left[\begin{array}{lll}91110 & 120\end{array}\right]$} & {$\left[\begin{array}{ll}91 & 120\end{array}\right]$} \\
\hline $0-130$ & Kurang Tinggi & Trimf & {$\left[\begin{array}{lll}71 & 80 & 100\end{array}\right]$} & {$\left[\begin{array}{ll}71 & 100\end{array}\right]$} \\
\hline $0-130$ & Tidak Tinggi & Trimf & {$\left[\begin{array}{lll}61 & 70 & 80\end{array}\right]$} & {$\left[\begin{array}{ll}61 & 80\end{array}\right]$} \\
\hline
\end{tabular}

Tabel 4. Himpunan Fuzzy Variabel Berat Badan Balita

\begin{tabular}{|l|l|l|l|l|}
\hline $\begin{array}{c}\text { Semesta } \\
\text { Pembicaraan }\end{array}$ & \multicolumn{1}{|c|}{$\begin{array}{c}\text { Nama himpunan } \\
\text { Fuzzy }\end{array}$} & Model MF & Parameter & Domain \\
\hline $0-26$ & Sangat Berat & Trimf & {$\left[\begin{array}{lll}18 & 20 & 26\end{array}\right]$} & {$\left[\begin{array}{ll}18-26\end{array}\right]$} \\
\hline $0-26$ & Berat & Trimf & {$\left[\begin{array}{lll}12 & 15 & 19\end{array}\right]$} & {$\left[\begin{array}{lll}12-19\end{array}\right]$} \\
\hline $0-26$ & Kurang Berat & Trimf & {$\left[\begin{array}{lll}8 & 9 & 13\end{array}\right]$} & {$\left[\begin{array}{lll}8 & -13\end{array}\right]$} \\
\hline $0-26$ & Tidak Berat & Trimf & {$\left[\begin{array}{llll}0 & 8 & 9\end{array}\right]$} & {$\left[\begin{array}{ll}0- & 9\end{array}\right]$} \\
\hline
\end{tabular}


Penelitian Bidang Komputer Sains dan Pendidikan Informatika V1.i1(1-12)

Tabel 5.Himpunan FuzzyVariabel Sttaus Malnutrition

\begin{tabular}{|l|l|l|l|l|}
\hline \multicolumn{1}{|c|}{$\begin{array}{c}\text { Semesta } \\
\text { pembicaraan }\end{array}$} & $\begin{array}{c}\text { Nama } \\
\text { Himpunan } \\
\text { Fuzzy }\end{array}$ & \multicolumn{1}{|c|}{ Model MF } & Parameter & Domain \\
\hline $0-1$ & Tidak & Trapf & {$\left[\begin{array}{llll}0.5 & 0.7 & 1\end{array}\right]$} & $0.5-1$ \\
\hline $0-1$ & Ya & Trapf & {$\left[\begin{array}{lll}0 & 0.3 & 0.4\end{array}\right]$} & $0-0.4$ \\
\hline
\end{tabular}

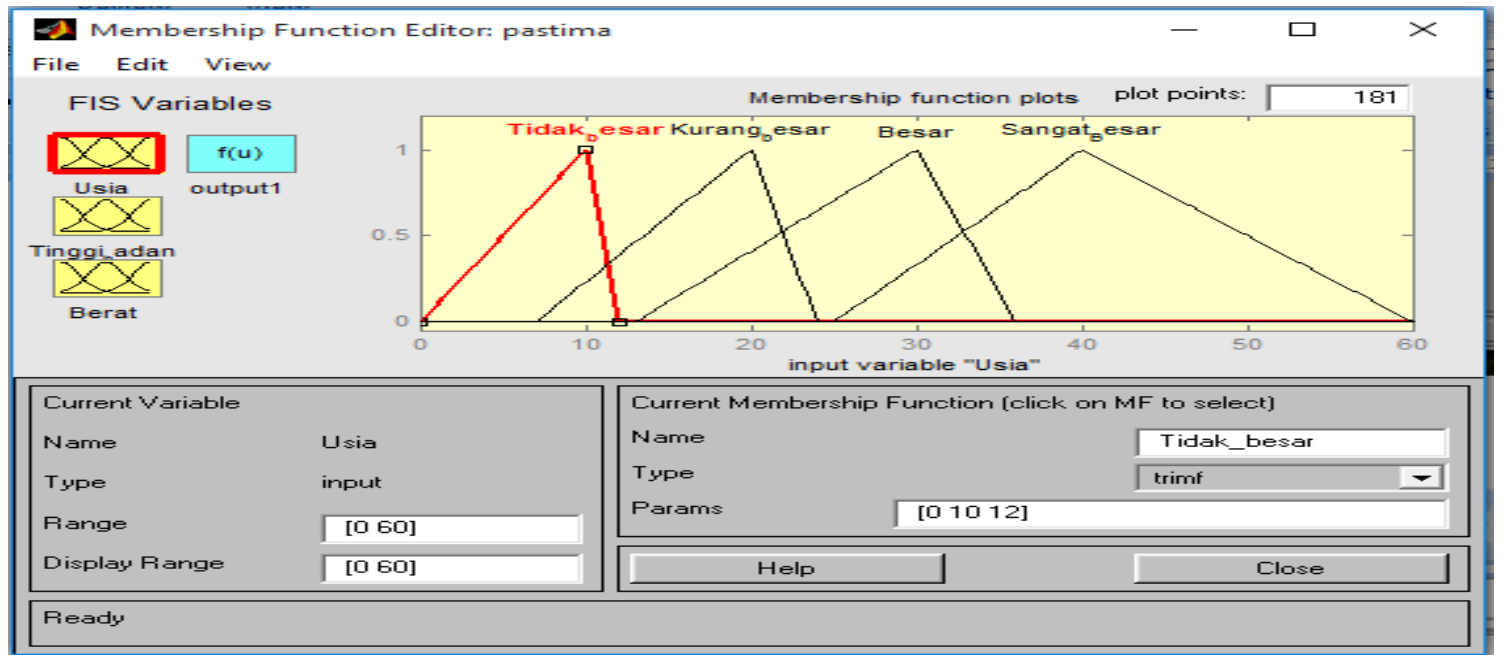

Gambar 1.Membership FunctionUntuk Variabel Usia

Pada variabel usia balita, data yang dimiliki dapat dibagi menjadi 4 himpunan

$$
\left\{\begin{array}{lr}
1 ; & x \leq 10 \\
(12-x) /(12-10) & 0 \leq x \leq 12 \\
0 ; & \leq x 12
\end{array}\right.
$$
fuzzy, yaitu: Tidak Tinggi, kurang Tinggi,

Tinggi, sangat Tinggi.Himpunan fuzzy tidak Tinggi akan memiliki domain [0 - 12]. Himpunan fuzzy kurang tinggi memiliki domain[7- 24]. Himpunan fuzzy tinggi memiliki domain[13-36]. Himpunan fuzzy sangat tinggi memiliki domain[25- 60]. Bentuk perhitungan variable usia secara manual :

$$
\begin{gathered}
\mu \text { KurangTinggi }= \\
\left\{\begin{array}{l}
0 ; \quad x \leq 7 \text { atau } x \geq 24 \\
(x-24) /(20-7) ; 7 \leq x \leq 24 \\
(24-x) /(24-20) ; 20 \leq x \leq 24
\end{array}\right. \\
\quad \mu l \text { Tinggi }= \\
\left\{\begin{array}{l}
0 ; \quad x \leq 13 \text { atau } x \geq 36 \\
(x-13) /(30-13) ; 30 \leq x \leq 13 \\
(36-x) /(36-30) ; 30 \leq x \leq 36
\end{array}\right.
\end{gathered}
$$

$\mu$ TidakTinggi $=$

$\mu$ SangatTinggi $=$ 


$$
\begin{cases}0 ; & x \leq 25 \\ (x-60) /(60-40) ; & 40 \leq x \leq 60 \\ 1 ; & x \geq 60\end{cases}
$$

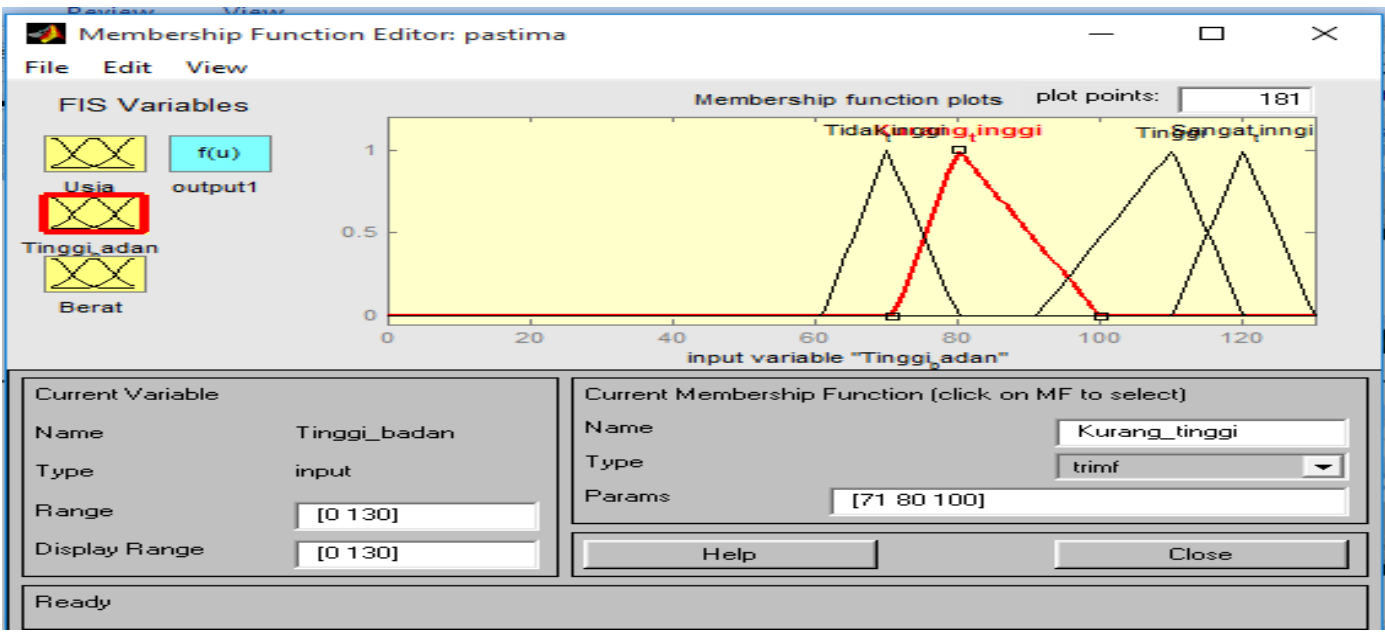

Gambar 2.Membership FunctionUntuk Variabel Tinggi Badan Balita

Pada variabel tinggi badan balita,data yang dimiliki dapat dibagi menjadi 4 himpunan fuzzyyaitu: badan balita tidak tinggi, badan balita kurang tinggi, badan balita tinggi, badan balita sangat tinggi. Himpunan fuzzybadan balita tidak tinggi akan memiliki domain [61-80]. Himpunan fuzzy badan balita kurang tinggi memiliki domain[71-100]. Himpunan fuzzy badan balitatinggi memiliki domain[90-120]. Himpunan fuzzy badan balita sangattinggi memiliki domain[110-130]. Bentuk Himpunan variabel tinggi badan balita dapat dilihat pada persamaan berikut:

$$
\begin{aligned}
& \mu \text { TidakTinggi }=
\end{aligned}
$$

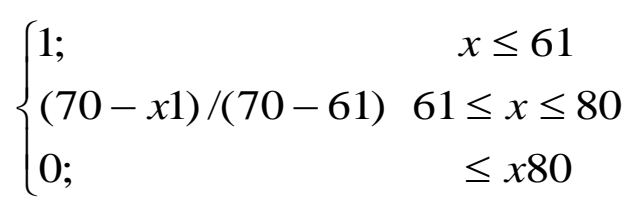

$$
\begin{aligned}
& \begin{cases}0 ; & x \leq 110 \\
(x-110) /(120-110) ; & 110 \leq x \leq 120 \\
1 ; & x \geq 130\end{cases}
\end{aligned}
$$

$\mu$ KurangTinggi $=$

$$
\left\{\begin{array}{l}
0 ; \quad x \leq 71 \text { atau } x \geq 100 \\
(x-71) /(80-71) ; 71 \leq x \leq 80 \\
(80-x) /(80-71) ; 80 \leq x \leq 100
\end{array}\right.
$$

\section{$\mu$ Tinggi $=$}

$$
\left\{\begin{array}{l}
0 ; \quad x \leq 90 \text { atau } x \geq 120 \\
(x-90) /(100-90) ; 90 \leq x \leq 100 \\
(100-x) /(100-90) ; 100 \leq x \leq 120
\end{array}\right.
$$$$
\mu \text { SangatTinggi }=
$$ 


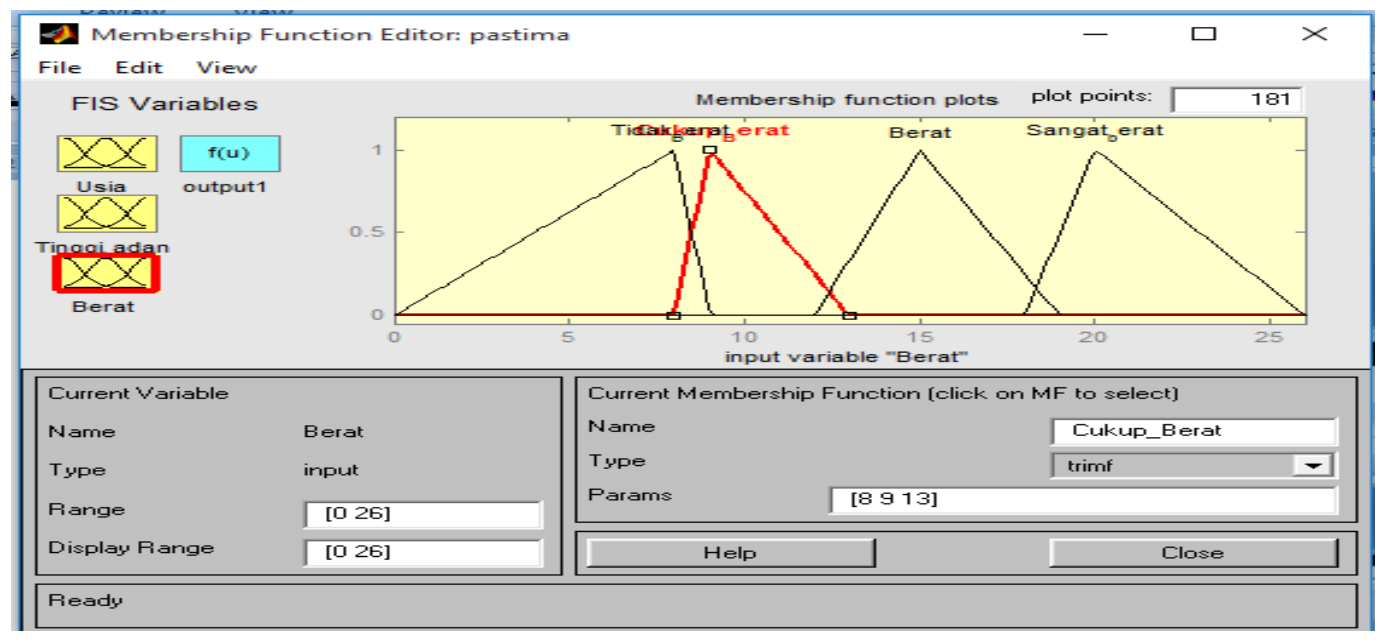

Gambar 3.Membership FunctionUntuk Variabel Berat Badan Balita $\mu$ KurangBerat $=$

Pada variabel berat badan balita, data yang dimiliki dapat dibagi menjadi 4 himpunan fuzzy, yaitu: Sangat Berat , Berat, Kurang Berat, Tidak Berat. Himpunan fuzzy tidak $\left\{\begin{array}{l}0 ; \quad x \leq 8 \text { atau } x \geq 13 \\ (x-8) /(9-8) ; 9 \leq x \leq 13 \\ (9-x) /(9-8) ; 9 \leq x \leq 13\end{array}\right.$ Berat akan memiliki domain [0-9], dengan derajat keanggotaan tidak Besar. Himpunan fuzzykurang Berat akan memiliki domain [ 8-13]. Himpunan fuzzy Berat akan memiliki domain [12-19], dengan derajat keanggotaan sangat Berat [18-26]. Himpunan tidak baik dapat dilihat pada persamaan berikut:

$$
\begin{gathered}
\mu \text { Berat }= \\
\left\{\begin{array}{l}
0 ; \quad x \leq 12 \text { atau } x \geq 19 \\
(x-12) /(13-12) ; 12 \leq x \leq 19 \\
(13-x) /(13-12) ; 12 \leq x \leq 19
\end{array}\right. \\
\mu \text { SangatBerat }=
\end{gathered}
$$

$$
\begin{aligned}
& \mu \text { TidakBerat= } \\
& \left\{\begin{array}{lr}
1 ; & x \leq 8 \\
(9-x) /(9-8) & 8 \leq x \leq 9 \\
0 ; & \leq x 9
\end{array}\right. \\
& \begin{cases}0 ; & x \leq 18 \\
(x-18) /(20-18) ; & 18 \leq x \leq 26 \\
1 ; & x \geq 26\end{cases}
\end{aligned}
$$




\section{Jurnal EdikInformatika E-ISSN : 2541-3716}

Penelitian Bidang Komputer Sains dan Pendidikan Informatika

V1.i1(1-12)

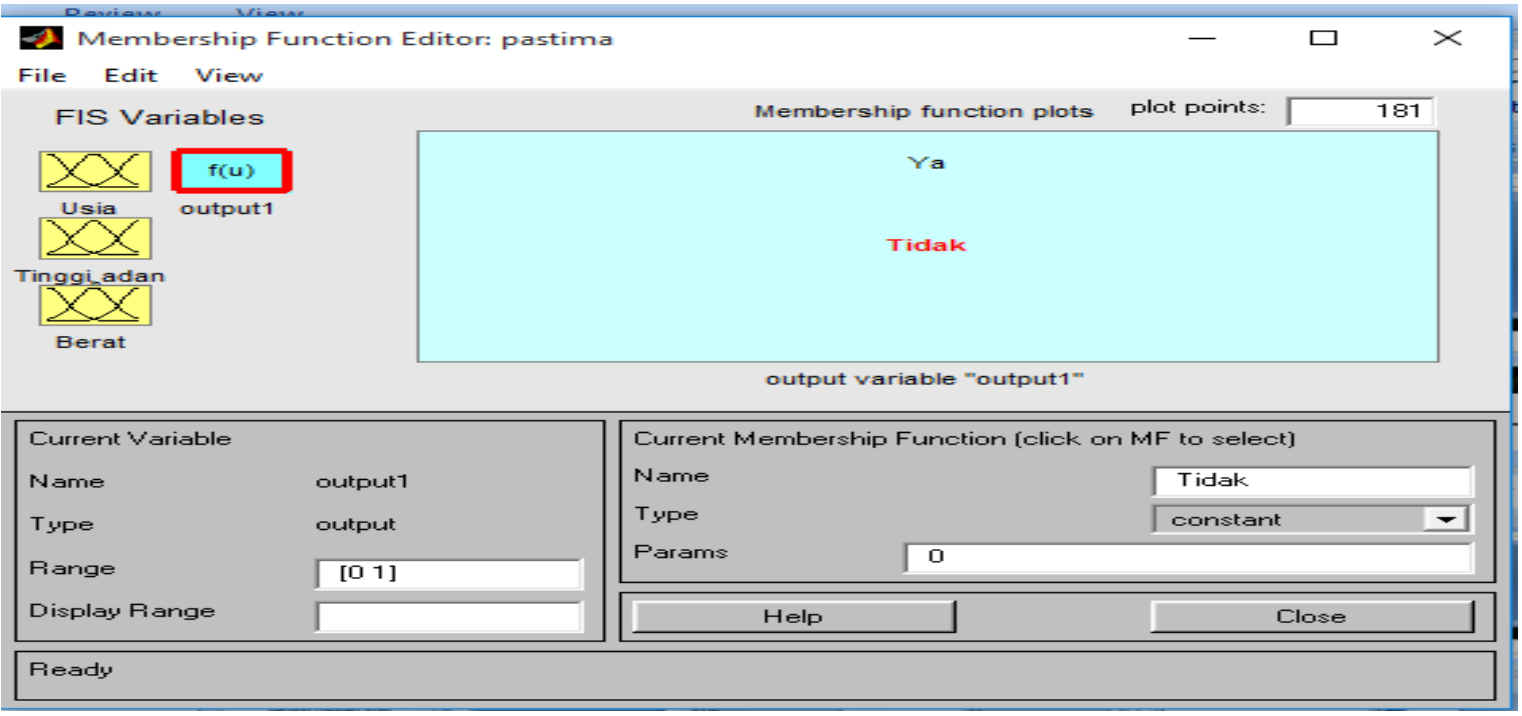

Gambar 4.Membership FunctionUntuk Variabel Status Malnutrition

Pada variabel Status Malnutrition, data yang dimiliki dapat dibagi menjadi 2 himpunan fuzzy, yaitu: ya dan tidak. Himpunan fuzzytidak akan memiliki domain [0.5 1] Himpunan fuzzyya akan memiliki domain [0 0.4$]$.

Input Usia $=45$ berada pada nilai linguistik Baik [25 40 60]. dengan menggunakan fungsi segitiga Untuk nilai linguistik tinggi derajat keanggotaannya dihitung dengan menggunakan rumus : $(c-x) /(c-b) ; b \leq x \leq c$

Dimana: $\quad x=45, b=40, c=60$

Input Usia [45] $=(c-x) /(c-b)=(60-45) /(60$ $-40)=15 / 20=0.75$

Input Tinggi Badan $=100$ berada pada nilai linguistik banyak [91 110 120] dengan menggunakan fungsi segitiga. Untuk nilai linguistik Layak derajat keanggotaannya

dihitung dengan menggunakan rumus : (c$x) /(c-b) ; b \leq x \leq c$

Dimana: $\quad x=100, a=95, b=110$

Tinggi Badan $\quad[100]=(x-a) /(b-a)=(100-$ $95) /(110-95)=5 / 15=0.33$

Input Tinggi Badan $=100$ berada pada nilai linguistik banyak [ $\left.\begin{array}{lll}71 & 80 & 100\end{array}\right]$ dengan menggunakan fungsi segitiga. Untuk nilai linguistik Layak derajat keanggotaannya dihitung dengan menggunakan rumus : $(c-$ $x) /(c-b) ; b \leq x \leq c$

Dimana: $x=100, b=80, c=100$

Tinggi Badan $\quad[100]=(c-x) /(c-b)$ $=(100-100) /(100-80)=0 / 20=0$ 


\section{ISSN : 2407-0491 \\ Jurnal EdikInformatika \\ E-ISSN : 2541-3716}

Penelitian Bidang Komputer Sains dan Pendidikan Informatika

V1.i1(1-12)

Input Berat $=19$ berada pada nilai linguistik Besar [18 20 26]. dengan menggunakan fungsi segitiga. Untuk nilai linguistik Setuju derajat keanggotaannya dihitung dengan menggunakan rumus $(c-x) /(c-b)$; $b \leq x \leq c$

Dimana: $\quad x=19 a=17, \mathrm{~b}=20$

Berat $[19]=(x-a) /(b-a)=(19-17) /(20-17)$ $=2 / 3=0.6$

Input Berat $=19$ berada pada nilai linguistik Berat [12 15 19]. dengan menggunakan fungsi segitiga. Untuk nilai linguistik Setuju derajat keanggotaannya dihitung dengan menggunakan rumus $(c-x) /(c-b)$; $b \leq x \leq c$

Dimana: $\quad x=19 b=17, \mathrm{c}=20$

Berat $[19]=(c-x) /(c-b) ;=(20-19) /(20-$ 17) $=1 / 3=0.3$

Dari hasil fuzzification menghasilkan3 fuzzy input yaitu :

1. Usia $=$ Sangat Tinggi $(0,75)$

2. Tinggi Badan= Tinggi $(0,33)$ dan cukup tinggi (0)

3. Berat Badan $=$ Sangat Berat $(0,6)$ dan Berat $(0,3)$

Aturan yang dipakai adalah berdasarkan angket yang disebar yaitu dari maksimal aturan yang dapat dibentuk dan yang terpilih paling banyak oleh responden untuk menyatakan relasi antara input dan output. Dari pemetaan tersebut terlihat bahwa maksimal aturan sebagai berikut :

1. [R1] IF (Usia is Tidak Tinggi) AND (Balita Tidak Tinggi) AND (Berat Badan tidak Berat) Then (Status malnutrition is Tidak).

2. [R2] IF (Usia is Tidak Tinggi) AND (Balita Tidak Tinggi) AND (Berat Badan Cukup Berat) Then (Status malnutrition is Tidak).

3. [R3] IF (Usia is Tidak Tinggi) AND (Balita Tidak Tinggi) AND (Berat Badan Berat) Then (Status malnutrition is Iya).

4. [R4] IF (Usia is Tidak Tinggi) AND (Balita Tidak Tinggi) AND (Berat Badan Sangat Berat) Then (Status malnutrition is Iya).

5. [R5] IF (Usia is Cukup Tinggi) AND (Balita Tidak Tinggi) AND (Berat Badan tidak Berat) Then (Status malnutrition is Tidak).

6. [R6] IF (Usia is Cukup Tinggi) AND (Balita Tidak Tinggi) AND (Berat Badan Cukup Berat) Then (Status malnutrition is Tidak).

7. [R7] IF (Usia is Cukup Tinggi) AND (Balita Tidak Tinggi) AND (Berat Badan Berat) Then (Status malnutrition is Iya).

8. [R8] IF (Usia is Cukup Tinggi) AND (Balita Tidak Tinggi) AND (Berat Badan Sangat Berat) Then (Status malnutrition is Iya). 
9. [[R9] IF (Usia is Tinggi) AND (Balita Tidak Tinggi) AND (Berat Badan Tidak Berat) Then (Status malnutrition is Iya).

10. [R10] IF (Usia is Tinggi) AND (Balita Tidak Tinggi) AND (Berat Badan Cukup Berat) Then (Status malnutrition is Tidak).

11. [R11] IF (Usia is Tinggi) AND (Balita Tidak Tinggi) AND (Berat Badan Berat) Then (Status malnutrition is Tidak).

12. [R12] IF (Usia is Tinggi) AND (Balita Tidak Tinggi) AND (Berat Badan Sangat Berat) Then (Status malnutrition is Tidak).

13. [R13] IF (Usia is Sangat Tinggi) AND (Balita Tidak Tinggi) AND (Berat Badan Tidak Berat) Then (Status malnutrition is Iya).

14. [R14] IF (Usia is Sangat Tinggi) AND (Balita Tidak Tinggi) AND (Berat Badan Cukup Berat) Then (Status malnutrition is Tidak).

15. [R15] IF (Usia is Sangat Tinggi) AND (Balita Tidak Tinggi) AND (Berat Badan Berat) Then (Status malnutrition is Tidak).
16. [R16] IF (Usia is Sangat Tinggi) AND (Balita Tidak Tinggi) AND (Berat Badan Sangat Berat) Then (Status malnutrition is Iya).

17. [R17] IF (Usia is Sangat Tinggi) AND (Balita SangatTinggi) AND (Berat Badan Sangat Berat) Then (Status malnutrition is Tidak).

18. [R18] IF (Usia is Sangat Tinggi) AND (Balita SangatTinggi) AND (Berat Badan Berat) Then (Status malnutrition is Tidak).

19. [R19] IF (Usia is Sangat Tinggi) AND (Balita SangatTinggi) AND (Berat Badan Cukup Berat) Then (Status malnutrition is Tidak).

20. [R20] IF (Usia is Sangat Tinggi) AND (Balita SangatTinggi) AND (Berat Badan Tidak Berat) Then (Status malnutrition is Iya).

Dengan menggunakan metode defuzzy weighted average, maka status malnutrition adalah sebagai berikut:

$$
\mathrm{Z}^{*}=
$$

$\frac{(0,75 * 45)+(0,33 * 100)+(0 * 100)+(0,6 * 19)+(0,33 * 19)}{0.75+0,33+0+0,6+0,33}+$

$$
Z^{*}=83.85
$$




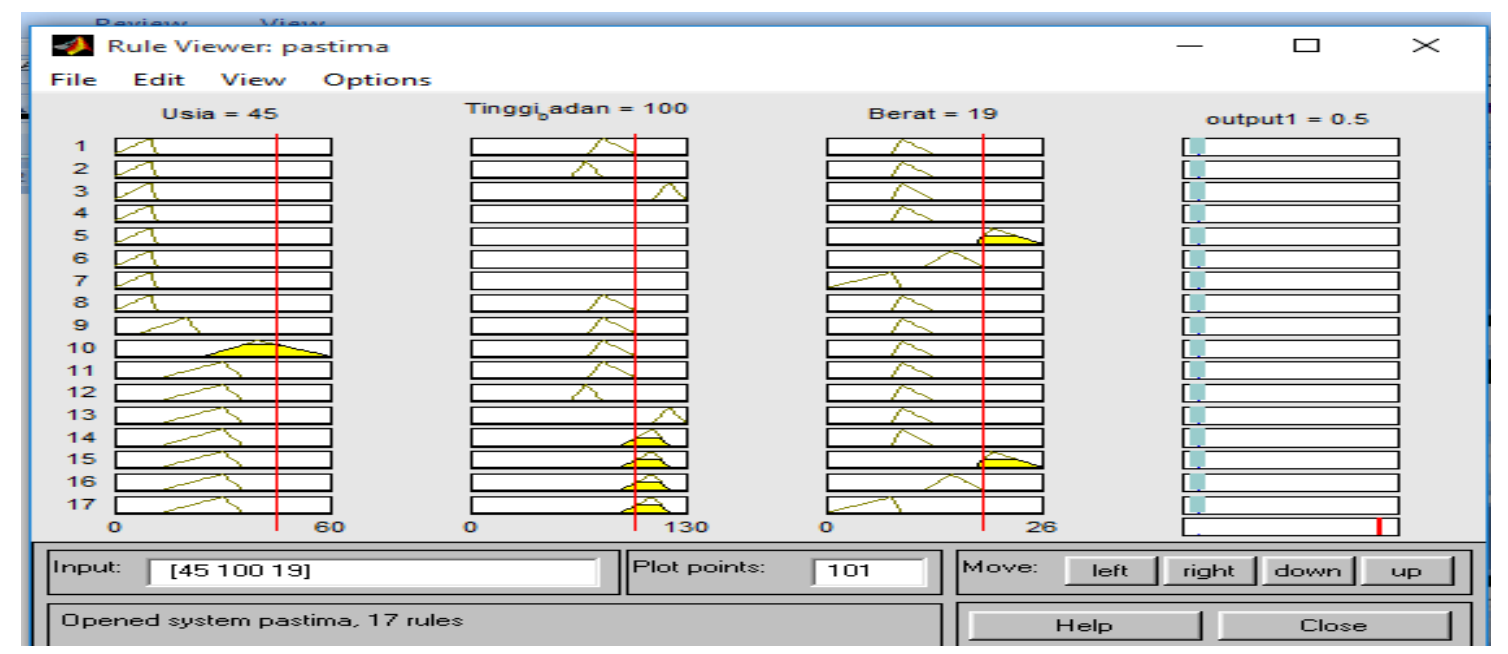

Gambar 5.Tampilan Rule Viewermalnutrition

Berdasarkan gambar 5 dapat dilihat bahwa nilai outputstatus malnutrition 83.85 . Nilai itu terletak pada himpunan fuzzytidak masuk dalam status malnutrition.

\section{KESIMPULAN}

Status malnutrition di Kota Batam berdasarkan Usia Balita, Tinggi Badan Balita dan Berat Badan Balita menggunakan aplikasi fuzzy Sugenoa dalah sebagai berikut:

1. Dengan menggunakan metode Sugeno dalam logika fuzzy bisa menentukan Status malnutrition di Kota Batam,

2. Logika fuzzy bisa digunakan untuk membantu dalam menentukan status malnutrition di Kota Batam

3. Dengan menerapkan metode Sugeno dalam logika fuzzy mampu menghasilkan output dalam status malnutrition di Kota Batam.

\section{UCAPAN TERIMAKASIH}

Terimakasih kepada teman-teman dosen dan mahasiswa yang telah membantu dalam penelitian ini dan juga kepada LPPM universitas Putera Batam yang memberikan waktu kepada peneliti untuk menyelesaikan penelitian.

\section{DAFTAR PUSTAKA}

Antika Thapar, Mehar Goyal, (2016) 'A fuzzy expert system for diagnosis of malnutrition in children', TeknoPedagogi, IEEE Region 10 Humanitarian Technology Conference (R10-HTC) - Agra, India.

Budiharto, W., \& Derwin Suhartono, (2014) '(2014). Artificial Intelligence. (P. Andi, Ed.). Yogyakarta. 


\section{Jurnal EdikInformatika E-ISSN : 2541-3716}

Penelitian Bidang Komputer Sains dan Pendidikan Informatika

V1.i1(1-12)

Dewi, K., Hartati, S., \& Purnomo, H. (2010). Aplikasi Logika Fuzzy Untuk

Pendukung

Keputusan. (G. I.

Yogyakarta, Ed.) (edisi kedua).

Yogyakarta.

Drs. Katen Lumbanbatu, Novriyeni, (2014).Sistem pakar mendiagnosa gizi buruk pada balita dengan metode fuzzy logic (studi kasus di RSUD. Dr. Rm. Djoelham Binjai).Jurnal KAPUTAMA, Vol.8 No.1.

Ewa Silander, RD, Jan Nyman, MD, PhD, Mogens Bove, $\mathrm{MD}, \mathrm{PhD}$, Leif Johansson, MD, PhD, Sven Larsson, MD, Eva Hammerlid, MD, PhD (2008). Impact of prophylactic percutaneous Endoscopic gastrostomy on malnutrition and Quality of life in patients with head and neck Cancera randomized study. Head \& Neck.

Hartati, S., \& Iswanti, S. (2008). Sistem

Pakar dan Pengembangannya. (G.

Ilmu, Ed.) (Pertama).

Yogyakarta.

Harto, W. B., \& Suhartono, D. (2014).

Artificial Intelligence. (P. Andi, Ed.).

Yogyakarta.

LPPM, (2018) 'Panduan Pengabdian

Kepada Masyarakat Universitas

Putera Batam Batam: LPPM

Universitas Putera Batam.

Sugiyono. (2012). Metode Penelitian

Manajemen. Edisi pertama.
S.Wieskotten, S Heinke, P Wabel, U Moissl, J Becker, M Pirlich, M Keymling and R Isermann (2008). Bioimpedance-based identification of malnutrition using fuzzy logic. Physiological Measurement IOP Publishing Physiol. Meas. 29 (2008) 639-654.

T.Sutojo, Mulyanti, E., \& Suhartono, V. (2011). Kecerdasan Buatan. (A. Yogyakarta, Ed.). Yogyakarta.

ALFABETA, Bandung. 